\title{
Factors Affecting the Amount of Investment Loans in Commercial Banks with the Application of Linear Regression Analysis Methods
}

\author{
K. Joebaedi ${ }^{1 *}$, D. Susanti ${ }^{2}$, N. Warwah ${ }^{3}$, K. Parmikanti ${ }^{4}$, \\ Badrufalah $^{5}$ \\ ${ }^{1-5}$ Mathematics Department, Faculty Mathematics and Natural Sciences, \\ Universitas Padjadjaran, Bandung, Indonesia \\ *E-mail: khafsah.joebaedi@unpad.ac.id
}

\begin{abstract}
Several factors can affect the amount of investment credit issued by the bank. This study discusses the effect of interest rates, inflation rates, capita income, and the number of medium-large industries on the number of investment loans, using the method of linear regression analysis. The independent variables examined to determine the influence of each and all the independent variables on the number of investment loans in commercial banks, namely interest rates, inflation rates, capita income, and the number of mediumlarge industries using the parameter estimation method, OLS (Ordinary Least Square).
\end{abstract}

Keywords : linear regression, variables, independent, investment loans

\section{Introduction}

Investment Credit is credit issued by a bank for the purpose of purchasing business capital goods. Several factors can affect the amount of investment credit issued by the bank. In this study only investigated the influence of interest rates, inflation rates, capita income, and the number of large medium industries to the amount of investment credit[3].

Banking has an important role because in accordance with its function is to collect and channel funds in the community, while the aim is to support the implementation of national development in order to increase equity in economic growth and national stability towards improving people's welfare[3].

Knowing the factors that are very influential on investment credit, people are easier to take investment loans. The world of banking through investment credit will later play a direct or indirect role in the economy of society, the state, and the banking world itself[1].

Banking activities are also needed to conduct a business activity in which banks also provide investment credit services as an effort to launch a business that is being undertaken. This investment credit service is an easy solution for new entrepreneurs who create jobs and to support them. Loans increase the expansion of employment, reduce unemployment and credit can increase income distribution in the implementation of development[5].

\section{Methodology}

48 IEKSAKTA: Berkala IImiah Bidang M IPA 
The stages of analysis used are illustrated in the flowchart as follows,

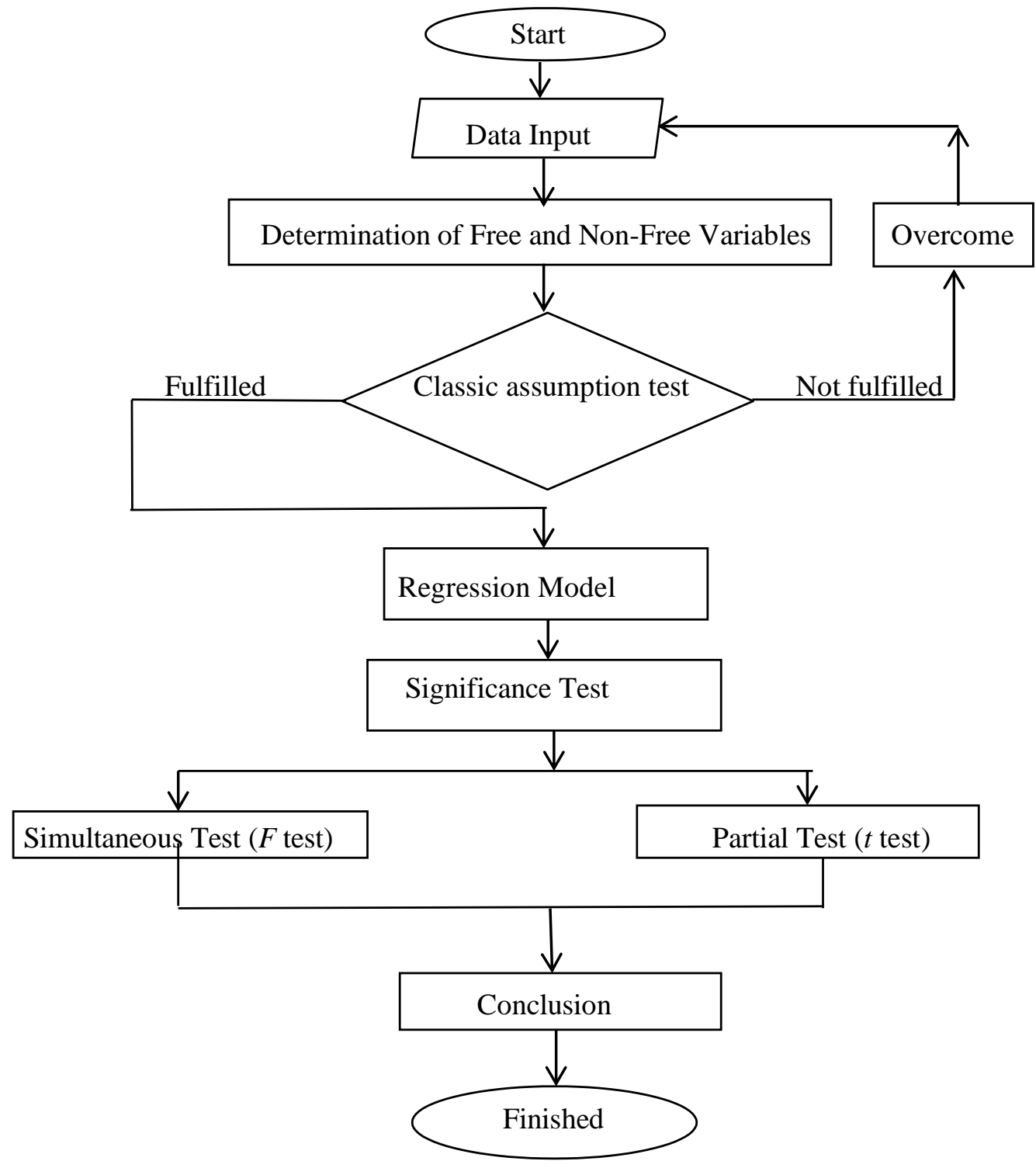

Figure 1. Flowchart of data processing methods

The flowchart above is a brief explanation of the steps taken in analyzing the amount of investment credit in Indonesian commercial banks[2]. The full description of the sequence of analysis steps will be explained as follows:

1. Test data by performing a classic assumption test consisting of 4 assumption tests, namely multicollinearity assumption test, heteroscedasticity assumption test, normality assumption test, and autocorrelation assumption test.

2. The data that meets the test requirements of the assumption will be directly determined by the regression model, while the data that does not meet the assumption test requirements will be addressed first so that the data can meet the assumption test and the estimation model can be estimated[7].

3. Determine the estimated model so that the regression model is obtained

49 IEKSAKTA: Berkala IImiah Bidang MIPA 
4. Test the regression model that has been obtained by the significance test or significance test of the regression model. Simultaneous test ( $F$ test) to find out whether the regression model can be used as an estimator, and partial test ( $t$ test) to find out the closeness relationship between the independent variable and the dependent variable.

5. Make research conclusions.

3. Results and Discussion Classical Assumption Test Results

1. Test for Normality Assumptions

2. One-Sample Kolmogorov-Smirnov Test

\begin{tabular}{|c|c|c|c|c|c|}
\hline \multirow[b]{2}{*}{$\mathrm{N}$} & & \multirow[t]{2}{*}{ Interest Rate } & $\begin{array}{l}\text { Inflation } \\
\text { rate }\end{array}$ & $\begin{array}{l}\text { Income } \\
\text { per capita }\end{array}$ & $\begin{array}{c}\text { Amount of } \\
\text { Large- } \\
\text { Medium } \\
\text { Industries }\end{array}$ \\
\hline & & & 27 & 27 & 27 \\
\hline Normal & Mean Parameters & 16.6956 & .9019 & 16.0519 & .1081 \\
\hline a, b & Std. Deviation & 2.95819 & .27861 & 9.78655 & .74906 \\
\hline Most Extreme & Absolute & .079 & .199 & .203 & .092 \\
\hline \multirow[t]{2}{*}{ Differences } & Positive & .079 & .199 & 203 & .092 \\
\hline & Negative & -.062 & -.112 & -.109 & -.092 \\
\hline \multicolumn{2}{|c|}{ Kolmogorov-Smirnov Z } & .409 & 1.033 & 1.057 & .480 \\
\hline \multicolumn{2}{|c|}{ Asymp. Sig. (2-tailed) } & .996 & .236 & .214 & .975 \\
\hline
\end{tabular}

a. Test distribution is Normal

b. Calculated from data.

Can be concluded that the independent variable interest rates, inflation rates, capita income, and the number of large industries is normally distributed[11].

2 Test for Multicollinearity Assumptions

\begin{tabular}{rlcc}
\hline \multirow{2}{*}{ Model } & \multicolumn{2}{c}{ Collinearity Statistics } \\
\cline { 3 - 4 } & Interest Rate & Tolerance & VIF \\
\hline \multirow{2}{*}{ Inflation Rate } & .931 & 1.074 \\
Capita Income & .449 & 2.226 \\
& & .404 & 2.472 \\
\end{tabular}


Dependent Variable: Amount of Investment Credit.

The VIF value for the Interest Rate variable is 1.074, the Inflation Rate variable is 2.226, the Income capita variable is 2.472, and the Medium-Large Amount Industry variable is 1.135. VIF value of the interest rate independent variable, inflation rate, income capita, and the number of large medium industries is smaller than 10. Then it can be said that these variables do not occur multicollinearity.

3. Test for Assumption of Heteroscedasticity

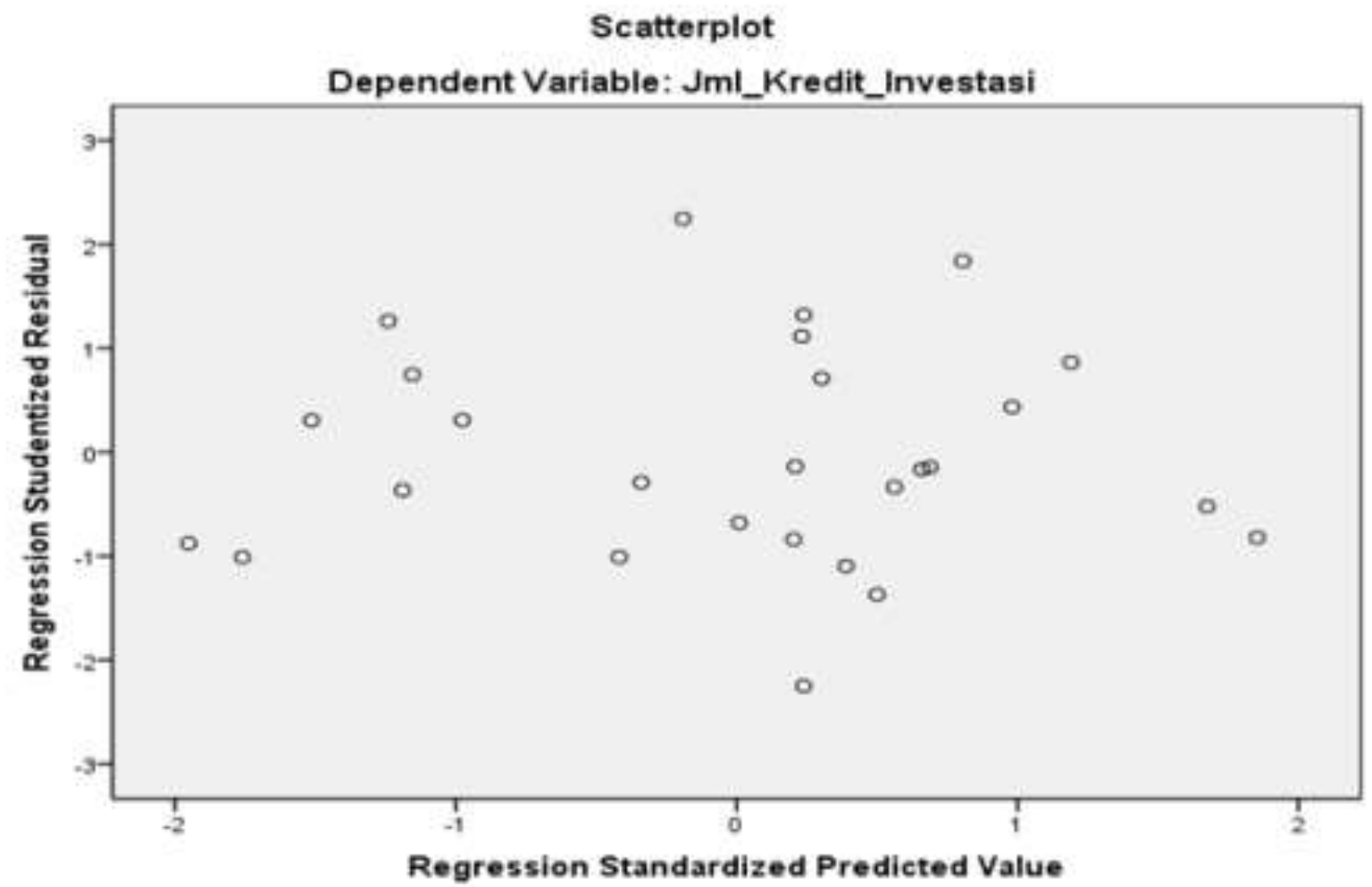

From the analysis of the output of IBM SPSS Statistics 19 (scatterplot image) above, we find points spread below and above the $\mathrm{Y}$ axis, and do not have a regular pattern. So, the conclusion is that the independent variables above do not occur heteroscedasticity or are homoskedasticity.

4. Autocorrelation Assumption Test

\begin{tabular}{ccrccc}
\multicolumn{7}{c}{} & \multicolumn{5}{c}{$\begin{array}{c}\text { Model } \\
\text { Summary }\end{array}$} \\
\hline Model & R & R Square & Adjusted & Std. Error of \\
the & Durbin- \\
\hline 1 & $289^{\mathrm{a}}$ & .083 & -.083 & 12.24428 & 1.135 \\
\hline
\end{tabular}

a. Predictors: (Constant), Amount of Large-Medium

51 IEKSAKTA: Berkala IImiah Bidang MIPA 
Industries, Interest Rate, Inflation Rate, capita Income.

b. Dependent Variable: Amount of Investment Credit

From the analysis of the output of IBM SPSS Statistics 19 above, the value of Durbin-Watson test $=1.135$ is obtained and means that DW is between DW.

Then it can be concluded that the above data does not occur autocorrelation.

\section{Results of Linear Regression Analysis}

To determine the linear regression coefficient, the equation is used[4]

The results are as follows.

$$
\hat{\beta}=\left(X^{\prime} X\right)^{-1} X^{\prime} y \text {. }
$$

$$
\left[\begin{array}{l}
\beta_{0} \\
\beta_{1} \\
\beta_{2} \\
\beta_{3} \\
\beta_{4}
\end{array}\right]=\left[\begin{array}{c}
16.02066001 \\
-1.789850139 \\
46,36358517 \\
-0.436282513 \\
2.196380982
\end{array}\right]
$$

After all the regression coefficient values are obtained, a linear regression model can be formed

with the following four independent variables:

$$
\begin{gathered}
\widehat{Y}_{l}=16.02066001-1.789850139 X_{1 i}+46.36358517 X_{2 i}-0.436282513 X_{3 i} \\
+2.196380982 X_{4 i}
\end{gathered}
$$

if this regression model is represented, the model becomes:

Amount of Credit Investment $=16.02066001 *$ Interest Rate

$-1.789850139 *$ Inflation Rate $+46.36358517 *$ capita Income $-0.436282513 *$ Amount of Large-Medium Industries.

5. Test the Significance of the Model Amount of Investment Credit

a. Simultaneous Test of Model Significance

$$
F=\frac{R K R}{R K S}=\frac{747.4907394}{240.4348928}
$$

Variance Analysis Table

\begin{tabular}{lccc}
\hline $\begin{array}{l}\text { Source of } \\
\text { Variance }\end{array}$ & $\begin{array}{c}\text { Degree of } \\
\text { Freedom }(\mathbf{d f})\end{array}$ & $\begin{array}{c}\text { Number of } \\
\text { squares }(\mathbf{J K})\end{array}$ & $\begin{array}{c}\text { Average Number of } \\
\text { Squares }(\mathbf{R J K})\end{array}$ \\
\hline Regression & 4 & 2989.962958 & $R K R=747.4907394$
\end{tabular}




$\begin{array}{cccc}\text { Remains } & 27-4-1=22 & 5289.56762 & R K S=240.4348928 \\ \text { Total } & 27-1=26 & 8279.5306 & K R T=\frac{8279.5306}{26}= \\ & & & 3184434846\end{array}$

$F_{(\mathrm{d} ; \mathrm{k} ; \mathrm{n}-\mathrm{k}-1)}=F_{(0,05 ; 4 ; 22)}=2.82$

$F_{\text {count }}>F_{\text {table, }}$

then $H_{0}$ rejected (accept $H_{a}$ ). $H_{a}$ acceptance shows that independent variables can explain changes in non-independent variables. This means that the influence factors of interest rates, inflation rates, capita income, and the number of large industries is being able to jointly explain the amount of investment credit.

b. Partial Test of Model Significance

\begin{tabular}{ccc}
\hline $\boldsymbol{t}_{\text {count }}$ & Value & $\boldsymbol{t}_{\text {count }}=\boldsymbol{t}_{\left(\frac{\boldsymbol{a}}{2}, \mathbf{n - k - 1}\right)}=\boldsymbol{t}_{\left(\frac{\boldsymbol{a}}{2}, \mathbf{2 2}\right)}$ \\
$=\mathbf{2 , 0 7 4}$
\end{tabular}

After all regression coefficients are tested, the results obtained that the independent variable that has the dominant effect on the dependent variable $Y$ is $X_{2}$. While variables $X_{1}, X_{3}$ and $X_{4}$ do not affect the $Y$ variable.

\section{Calculation Results of the Determination Coefficient}

$R^{2}$ Calculation:

$$
R^{2}=\frac{K J R}{J K T}=\frac{\sum \hat{y}_{i}^{2}}{\sum y_{i}^{2}}=\frac{2989.962958}{8279.5306}=0.36112711
$$

From the results of the calculation above, the value of $R^{2}$ is 0.36112711 . The decision to accept the model obtained is good or not can be seen from the coefficient of determination and the results of the $F$ test together, then in this study it can be concluded that the effect of the independent variable in this study is the interest rate $\left(X_{1}\right)$, inflation rate $\left(X_{2}\right)$, capita income $\left(X_{3}\right)$ and the number of large and medium industries for the number of investment loans in Indonesian commercial banks is $36.11 \%$, which means that $63.89 \%$ is influenced by other independent variables not included in this study. The results of the $F$ test also show that the interest rate $\left(X_{1}\right)$, inflation rate $\left(X_{2}\right)$, capita income $\left(X_{3}\right)$ and the number of large and medium industries $\left(X_{4}\right)$ have a significant effect on the amount of investment credit in Indonesian commercial banks $(Y)$. From the calculation of the coefficient of determination and the $F$ test, it can be concluded that the variables $X_{1}, X_{2}, X_{3}$ and $X_{4}$ simultaneously have a significant effect on the $Y$ variable, but 
the closeness is only $36.11 \%$. To produce a maximum value or close to 1 , you can add data and add other independent variables[6].

\section{Conclusion}

The results of the research can be summarized as follows:

Based on testing (simultaneous / concurrent) shows that there is a simultaneous influence between factors

$$
\begin{aligned}
& X_{1}=\text { Interest Rate } \\
& X_{2}=\text { Inflation Rate } \\
& X_{3}=\text { capita Income } \\
& X_{4}=\text { Amount of Medium-Large Industries }
\end{aligned}
$$

towards $(Y)$ Amount of Investment Loans in Indonesian Commercial Banks And based on the $t$ test shows that the most dominant factor influencing the Amount of Investment Loans in Indonesian Commercial Banks is the Inflation Rate.

\section{References}

[1] Gurajati, D. 1988. Ekonometrika Dasar. Jakarta: Erlangga T., M.

[2] Irianto, A. 2004. Statistik Konsep Dasar dan Aplikasinya. Jakarta: Prenada Media Group.

[3] Iskandar, S. 2008. Bank dan Lembaga Keuangan Lain. Jakarta: PT.Semesta Asa Bersama.

[4] Kurtner, M.H., Nachstheim dan J. Neter. 2004. Applied Linear Regression Models. New York McGraw Hill.

[5] Pengertian Definisi Operasional. http://www.id.svhoong.com, (diakses 10 Maret 2013).

[6] Rosadi, D. 2012. Ekonometrika dan Analisis Runtun Waktu Terapan dengan Eviews.

[7] Sudjana. 2005. Metoda Statistika. Bandung: Tarsito.

[8] Sunyoto, D. 2011. Analisis Regresi dan Uji Hipotesis. Yogyakarta : Caps.

[9] Siegel, S dan Castellan Jr, N.J. 1988. Nonparametric Statistics for The Behavioral Sciences. New York: McGraw Hill Humanities

[10] Sulistyana, A. 2010. Analisis Beberapa Faktor Yang Mempengaruhi Kredit Investasi Pada Bank Umum Di Jawa Timur. Jawa Timur: UPN "Veteran" Jatim 